\title{
Synechococcus and Prochlorococcus cell death induced by UV radiation and the penetration of lethal UVR in the Mediterranean Sea
}

\author{
Moira Llabrés ${ }^{1, *}$, Susana Agustí1 ${ }^{\text {, Patricia Alonso-Laita }}{ }^{1}$, Gerhard J. Herndl ${ }^{2,3}$ \\ ${ }^{1}$ Department of Global Change Research, IMEDEA (CSIC-UIB) Instituto Mediterráneo de Estudios Avanzados, \\ Miquel Marqués 21, 07190 Esporles, Mallorca, Spain \\ ${ }^{2}$ Department of Biological Oceanography, Royal Netherlands Institute for Sea Research, PO Box 59, 1790 AB Den Burg, \\ Texel, The Netherlands \\ ${ }^{3}$ Department of Marine Biology, University of Vienna, Vienna Ecology Center, Althanstr. 14, 1090 Vienna, Austria
}

\begin{abstract}
Irradiation experiments performed on natural communities of picocyanobacteria from the southwest Mediterranean Sea indicated that natural levels of solar ultraviolet radiation (UVR: 280 to $400 \mathrm{~nm}$ ) induced important cell death in Prochlorococcus sp., although Synechococcus sp. appeared to be highly resistant. In the treatments where UVB radiation (UVBR, 280 to $315 \mathrm{~nm}$ ) was excluded, Prochlorococcus also experienced high cell death with short half-life times of $3.01 \pm 0.1 \mathrm{SE}$ (h), showing the contribution of UVA radiation (UVAR, 315 to $400 \mathrm{~nm}$ ) and photosynthetically active radiation (PAR, 400 to $700 \mathrm{~nm}$ ) to Prochlorococcus cell death. Underwater radiometric measurements conducted during the cruise indicated that penetration of UVR was significant in the Mediterranean waters studied, with minimum diffuse attenuation coefficients of 0.165 and $0.071 \mathrm{~m}^{-1}$ for 313 and $380 \mathrm{~nm}$, respectively. The lethal UV doses required to decrease the picocyanobacteria populations by half, UVLRD ${ }_{50}$, calculated experimentally, were related to underwater UVR penetration in the Mediterranean Sea measured during the cruise. By calculating (from incident irradiances and UVR penetration) the daily UV doses at different depths in the water column, we found that, for sunny days, experimental Prochlorococcus $\mathrm{LRD}_{50}\left(187 \mathrm{~kJ} \mathrm{~m}^{-2}\right)$ could reach from 10 to $26 \mathrm{~m}$ depth. For Synechococcus, however, the depth receiving daily UVLRD $\mathrm{UL}_{50}\left(1375 \mathrm{~kJ} \mathrm{~m}^{-2}\right)$ was always shallower, above $5 \mathrm{~m}$ depth. The differential sensitivity of the 2 genera and the UV transparency of the Mediterranean Sea suggest that solar radiation could be an important factor influencing the dynamics and distribution of cyanobacterial populations in the surface waters of this oligotrophic sea.
\end{abstract}

KEY WORDS: Prochlorococcus · Synechococcus - Mediterranean Sea · UV radiation · Cell death · UV penetration $\cdot$ Diffuse attenuation coefficient $\cdot \mathrm{UVLRD}_{50}$

\section{INTRODUCTION}

Solar ultraviolet radiation (UVR: 280 to $400 \mathrm{~nm}$ ) reaching the earth's surface is affected by both stratospheric ozone depletion, induced by the release of anthropogenic compounds in the atmosphere, and global warming (Blumthaler \& Ambach 1990, Madronich et al. 1998, Weatherhead \& Andersen 2006). UVR has detrimental effects on aquatic ecosystems through damage to DNA and the production of reactive oxygen species (ROS). The latter leads to the inhibition of primary production in phytoplankton communities (Cullen et al. 1992, Vincent \& Neale 2000, Helbling et al. 2001). To protect against solar UVR, phytoplankton have developed a variety of photoprotection systems and different mechanisms to repair UV-induced cell damage (Roy 1999). However, protective systems and repair pathways are not always efficient, and cell death may be caused by UVR exposure in phytoplanktonic organisms, as demonstrated for picophytoplank- 
ton populations from the Atlantic Ocean (Llabrés \& Agustí 2006).

Even though the most harmful effects of UVR on living cells are generally attributed to UVB radiation (UVBR: 280 to $315 \mathrm{~nm}$ ), via DNA damage (Buma et al. 2001, Rijstenbil 2001), the negative effects of UVA radiation (UVAR: 315 to $400 \mathrm{~nm}$ ) on phytoplankton have also been observed, largely through the inhibition of primary production, pigment degradation and changes in nitrogen metabolism (Kim \& Watanabe 1994, Döhler \& Buchmann 1995, Forster et al. 1997, Conan et al. 2008). Although the energy yielded per photon is much lower in the UVA than in the UVB spectral domain, the total number of photons reaching the ocean surface is much higher for UVA leading to elevated irradiance values. Moreover, the attenuation of UVAR in the water column is lower than that of UVBR, which is efficiently absorbed by chromophoric matter (CDOM). Consequently, UVAR can penetrate many meters into the water column (8 to $46 \mathrm{~m}$ in oligotrophic oceans; Tedetti \& Sempéré 2006), affecting planktonic organisms over a large depth range compared to UVBR. Studies describing the penetration of UVR into oceanic waters are still scarce, and only recently Morel et al. (2007) described the UVR clearest oceanic waters located in the South Pacific gyre. In addition, the few measurements performed in the Mediterranean Sea indicate that these waters are very transparent to UVR (Tedetti \& Sempéré 2006). Although the impact of UVR on phytoplankton has been extensively reported, the relationship between UV-induced phytoplankton inhibition and the penetration of UVR has rarely been assessed.

In this study, we evaluated the lethal effect of natural solar radiation on picocyanobacteria communities of the Mediterranean Sea (Synechococcus and Prochlorococcus) through the measurements of half-life times and lethal UV doses required to reduce the picocyanobacteria populations by half $\left(\mathrm{UVLRD}_{50}\right)$. We also tested whether UVAR + photosynthetically available radiation (PAR: 400 to $700 \mathrm{~nm}$ ), after removing UVBR, may induce cell death in these populations. Underwater UVR and PAR measurements were performed during the study and converted into daily doses to determine the ecological significance of $\mathrm{UVLRD}_{50}$ in the water column of the Mediterranean Sea.

\section{MATERIALS AND METHODS}

Study area and sampling. Experiments were performed on Mediterranean communities sampled during 2 cruises, EUBAL-II (June 2002), a coastal study on board the RV 'Mytilus', and BADE-I (SeptemberOctober 2003) on board the RV 'Pelagia', where an anticyclonic eddy located in the SW Mediterranean Sea was monitored. This anticyclonic eddy starts in September and remains at the south of the island of Ibiza in a stable position until March (Pascual et al. 2000). Parallel to the irradiation (on deck) experiments performed with phytoplankton populations, vertical profiles of picoplankton cell abundance and viability were done at 4 of the stations located across the anticyclonic eddy (Pascual et al. 2000). Additionally, depth profile samples (5 to $80 \mathrm{~m}$ ) for phytoplankton and biogeochemical variable analyses were collected with Niskin bottles during more than $28 \mathrm{~h}$ on alternate days, providing information about the study site.

The depth of the upper mixed layer (UML), an index of the stability of the water column, was calculated from CTD profiles as the shallowest depth at which water density differs from surface waters by more than $0.05 \mathrm{~kg} \mathrm{~m}^{-3}$.

Irradiation experiments. To test the effect of UVR on Mediterranean phytoplankton, 3 experiments were performed: one during EUBAL-II and 2 during BADE-I. Expt 1 was done on 25 September 2003 with seawater sampled from $5 \mathrm{~m}$ depth at a station located at $37^{\circ} 46^{\prime} \mathrm{N}, 2^{\circ} 32^{\prime} \mathrm{E}$, and Expt 2 was performed on 8 October 2003, with samples collected from $10 \mathrm{~m}$ depth at $37^{\circ} 39^{\prime} \mathrm{N}, 1^{\circ} 54^{\prime} \mathrm{E}$, both during the BADE-I cruise. Expt 3 was conducted during the EUBAL-II cruise on 20 June 2002, with samples collected at $5 \mathrm{~m}$ depth at $39^{\circ} 30^{\prime} \mathrm{N}, 2^{\circ} 34^{\prime} \mathrm{E}$, located in the Bay of Palma (Majorca, Spain). For Expts 1 and 2, 3 light conditions were used in duplicate: (1) full sun (FS) = PAR+ UVAR+UVBR, (2) PAR+UVAR and (3) dark. For Expt 3, only FS and dark conditions were used. Water samples were incubated in quartz and black bottles $(100 \mathrm{ml})$ in incubators on deck with sea-surface re-circulating water to maintain in situ temperature. Quartz bottles allowed FS to pass through with approximately $90 \%$ transmittance at all wavelengths, while the black bottles shielded off all the solar radiation. In Expts 1 and 2, UVBR was removed by covering quartz bottles with a film (Mylar-D, DuPont Teijin Films), which exhibited a transmittance of $0 \%$ between 300 and $314 \mathrm{~nm}$, increasing to $28 \%$ at $320 \mathrm{~nm}$ and allowing UVAR to pass through at longer wavelengths. The experiments started at 10:30 h (Expts 1 and 2) or 13:15 h (Expt 3) and lasted for $8 \mathrm{~h}$ (Expts 1 and 2) or $5 \mathrm{~h}$ (Expt 3). Duplicate samples $(2 \mathrm{ml})$ were taken from each treatment every $2 \mathrm{~h}$, except for the last sampling interval which was $3 \mathrm{~h}$ for Expt 1 and $4 \mathrm{~h}$ for Expt 2. Sampling intervals differed in Expt 3, in which $2 \mathrm{ml}$ samples were taken at shorter intervals of $15 \mathrm{~min}, 45 \mathrm{~min}, 3 \mathrm{~h}$ and $5 \mathrm{~h}$ from the beginning of the experiment.

Picoplankton cell abundance and viability. Picocyanobacteria (Prochlorococcus and Synechococcus) cells are an important component of the phytoplankton 
community in the summer Mediterranean Sea. The abundance of Prochlorococcus and Synechococcus cells, in the samples from the experiments and the vertical profiles, were determined on board by flow cytometric analysis of duplicated fresh samples using a FACSCalibur flow cytometer (Becton Dickinson). Picophytoplankton cell viability was determined by using the cell digestion assay (Agustí \& Sánchez 2002), a membrane permeability test that discriminates living from dead cells. The abundance of living cells after the cell digestion assay was quantified on board by using flow cytometry as described in Llabrés \& Agustí (2006).

Irradiance measurements. Solar radiation received underwater in the incubation tanks was measured in Expts 1 and 2 using a PUVR 2500 Biospherical Instruments radiometer which measures UVR at 6 wavelengths: 305, 313, 320, 345, 380, $395 \mathrm{~nm}$, with $10 \mathrm{~nm}$ Full-Width Half-Maximum (FWHM) standard, except 305 (controlled by atmospheric ozone cut off). The instrument also has a Photosynthetically Active Radiation (PAR, 400 to $700 \mathrm{~nm}$ ) sensor. Natural PAR and UVR were measured in the incubation tanks (the sensor was $0.3 \mathrm{~m}$ below surface) every $30 \mathrm{~min}$ during the experiments. UVR values obtained from the radiometric measurements at the different wavelengths were integrated using the trapezoidal Riedmann Sum (Keisler 1986). To determine the whole irradiance over the UVR range, integrations obtained between 300 and $400 \mathrm{~nm}$ were summed. The same calculation was done to determine total irradiance over UVB (300 to $315 \mathrm{~nm}$ ) and UVA (315 to $400 \mathrm{~nm}$ ) ranges. Then, UV doses were calculated by integrating the cumulative radiation received during the experiments up to the time of sampling. UV irradiation measurements were not determined in Expt 3. During Expts 1 and 2, incident solar radiation was measured by a Kipp \& Zonen CM11 pyranometer located onboard RV 'Pelagia', which measured global radiation between $310 \mathrm{~nm}$ and $2800 \mathrm{~nm}$ continuously.

During the BADE-I cruise, underwater UVR and PAR profiles were performed on 6 occasions around noon by using the PUVR 2500 radiometer. Underwater daily doses of total UV, UVB and UVA were calculated from the water column profiles by integrating the radiation values obtained from the single wavelength measurements at each station to the different spectral bands, using the trapezoidal Riedmann Sum (Keisler 1986), and also integrating the instantaneous measurements per $8 \mathrm{~h}$ of day length.

The diffuse attenuation coefficient $\left(\mathrm{K}_{\mathrm{d}}, \mathrm{m}^{-1}\right)$ was determined from linear regressions of natural logarithmic downwelling irradiance against depth.

The half-life time $\left(t_{1 / 2}\right.$, time required to decline to one-half of the initial cell density) of each population was calculated from the decay rate in the abundance of living cells when exposed to irradiance. UV lethal radiation doses, UVLRD ${ }_{50}$, represent the radiation exposure required for the phytoplankton living cell abundance to decrease to one-half of its original value. This parameter was calculated from the relationship between the natural logarithm of the living cell abundance and UV doses.

To establish the UVR reactive layer in the water column, the UVLRD ${ }_{50}$ determined from surface exposures was extrapolated to the measurements of daily UV doses obtained from different depths. However, this extrapolation did not consider the changes in spectral composition, which tend to exclude the shorter and more damaging wavelengths. Thus, the depths of LRD50 should be regarded as maximum estimates, with the actual depths being probably somewhat shallower.

Biogeochemical analyses. In situ temperature, salinity and relative fluorescence were measured in the water column from CTD casts. Water-column inorganic nutrients $\left(\mathrm{NH}_{4}, \mathrm{NO}_{3}, \mathrm{NO}_{2}, \mathrm{PO}_{4}\right)$ and DOC were also determined. The methods for determining inorganic nutrient concentrations followed JGOFS recommendations (Gordon et al. 1993). The concentrations of dissolved inorganic nutrients were determined in a TRAACS autoanalyzer immediately after sample collection and gentle filtration through $0.2 \mu \mathrm{m}$ filters (Acrodisc, Gelman Science). Samples for DOC were filtered through rinsed $0.2 \mu \mathrm{m}$ polycarbonate filters and sealed in pre-combusted $\left(450^{\circ} \mathrm{C}\right.$ for $\left.4 \mathrm{~h}\right)$ glass ampoules after adding $50 \mu \mathrm{l}$ of $40 \%$ phosphoric acid. The samples were stored frozen at $-20^{\circ} \mathrm{C}$ until analysis in the laboratory onshore. DOC concentrations of duplicate samples were determined using a Shimadzu TOC-5000 analyzer.

\section{RESULTS}

Maximum values of incident global radiation received during the experiments were high, and slightly higher on 25 September (Expt 1, Fig. 1) than on 8 October (Expt 2, Fig. 1). Consequently, underwater UVB and UVA doses received during Expt 2 (Table 1) were somewhat lower than those received in Expt 1, which presented some variations due to cloudiness (Fig. 1).

Water transparency varied slightly between the stations sampled (Table 2). The diffuse attenuation extinction coefficient $\left(\mathrm{K}_{\mathrm{d}}\right)$ was higher for $305 \mathrm{~nm}$ (between 0.222 and $0.242 \mathrm{~m}^{-1}$ ) and decreased with increasing wavelength (Table 2). PAR $\mathrm{K}_{\mathrm{d}}$ varied between 0.066 and $0.073 \mathrm{~m}^{-1}$ (Table 2), which represented a variability in the depth of the photic layer $(1 \%$ of the surface light) between 64 and $70 \mathrm{~m}$. The mixed layer depth was shallower than the photic layer and varied 


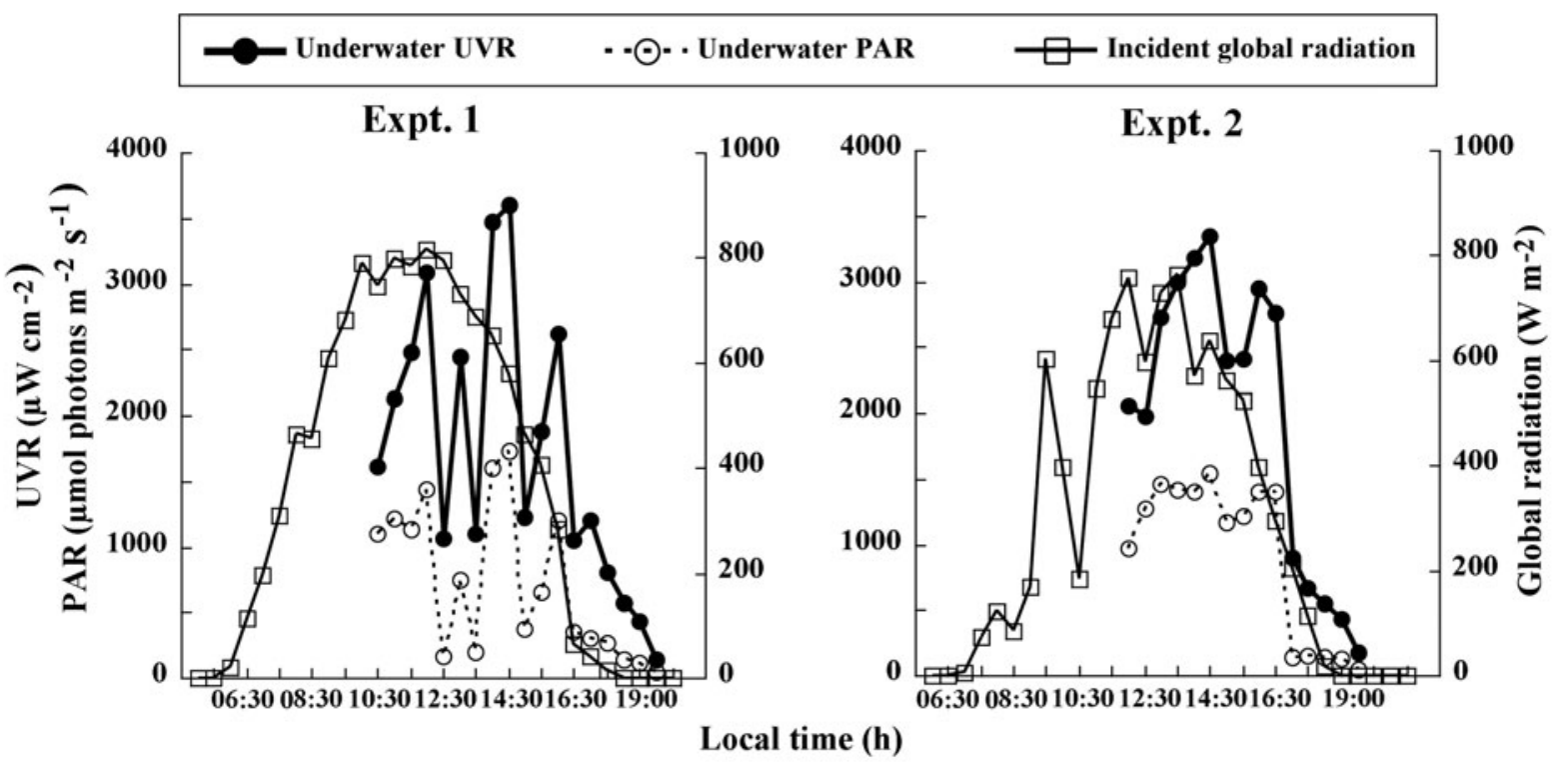

Fig. 1. Daily variation of incident global radiation $\left(\mathrm{W} \mathrm{m}^{-2}\right)$, underwater UV radiation (UVR, $\mu \mathrm{W} \mathrm{cm}^{-2}$ ) and photosynthetically active radiation (PAR, $\mu \mathrm{mol}$ photons $\mathrm{m}^{-2} \mathrm{~s}^{-1}$ ) in the experiments carried out during BADE-I cruise

between 21.8 and $27.7 \mathrm{~m}$ (Table 2). The area of study was oligotrophic, with low values of nutrients in surface waters (Table 3) and with a thermocline at around $40 \mathrm{~m}$ (Fig. 2). Close to the thermocline, there was a deep chlorophyll maximum with a parallel increase of nutrients (Table 3).

Picophytoplankton was dominated by Cyanobacteria, with Synechococcus sp. being more abundant at the surface than Prochlorococcus sp. (Fig. 2). During BADE-I, there were vertical differences in the distribution of picocyanobacteria, with Prochlorococcus exhibiting a low abundance close to the surface, increasing until about 30 to $40 \mathrm{~m}$ depth where maximum abundance was reached (Fig. 2) and sharply decreasing in abundance below (Fig. 2). Synechocococus followed a different distribution pattern, with 2 peaks in abundance: one close to the surface and a deeper one at about 40 to $50 \mathrm{~m}$ depth. Below this depth, Synechocococus abundance decreased (Fig. 2).

In all experiments, the abundance of living Prochlorococcus sp. decreased remarkably following exposure to total solar radiation (Fig. 3). However, Synechococcus sp. only showed cell death in Expts 1 and 3, with a moderate decrease in living cells (Fig. 3). In Expt 3, where the frequency of sampling was shorter, the abundance of living Prochlorococus strongly decreased after an exposure to UVR for only 45 min (Fig. 3). Dead cells, however, were still present in the total population, as indicated by the fact that total cell abundance did not decrease (Fig. 3). The abundance of the total population strongly decreased at the subsequent sampling interval ( $3 \mathrm{~h}$ of exposure) indicating that lysis of dead cells occurred (Fig. 3). The mortality of Prochlorococ-

Table 1. Underwater doses received during Expts 1 and 2, calculated for the different UV radiation (UVR) wavelengths measured $\left(\mathrm{kJ} \mathrm{m}^{-2} \mathrm{~nm}^{-1}\right)$, for integrated UVB and UVA radiation bands $\left(\mathrm{kJ} \mathrm{m}^{-2}\right)$ and for photosynthetically active radiation (PAR, mol photon $\mathrm{m}^{-2}$ )

\begin{tabular}{|c|c|c|c|c|c|c|c|c|c|}
\hline \multirow[t]{3}{*}{ Expt } & \multicolumn{8}{|c|}{$\longrightarrow$ UVR $\left(\mathrm{kJ} \mathrm{m}^{-2}\right)$} & \multirow{3}{*}{$\begin{array}{c}\text { PAR } \\
\left(\mathrm{mol} \text { photon } \mathrm{m}^{-2}\right)\end{array}$} \\
\hline & & $-\mathrm{Wa}$ & avelen & igth $(1$ & $\mathrm{nm})$ & & \multirow{2}{*}{$\begin{array}{c}\text { Integrated } \\
\text { UVB }\end{array}$} & \multirow{2}{*}{$\begin{array}{c}\text { Integrated } \\
\text { UVA }\end{array}$} & \\
\hline & 305 & 313 & 315 & 340 & 380 & 395 & & & \\
\hline 1 & 0.24 & 1.70 & 2.07 & 6.21 & 8.66 & 8.33 & 12 & 568 & 24 \\
\hline 2 & 0.23 & 1.55 & 1.88 & 5.62 & 7.73 & 8.54 & 11 & 526 & 25 \\
\hline
\end{tabular}

Table 2. Downwelling diffuse attenuation coefficients $\left(\mathrm{K}_{\mathrm{d}}\right)$ for spectral UVR and PAR, and the depth of the upper mixed layer (UML, $m$ ) in the Mediterranean Sea during BADE-1 cruise

\begin{tabular}{|c|c|c|c|c|c|c|c|c|}
\hline \multirow[t]{3}{*}{ Date } & \multicolumn{7}{|c|}{$-\mathrm{K}_{\mathrm{d}}\left(\mathrm{m}^{-1}\right)$} & \multirow{3}{*}{$\begin{array}{l}\text { UML } \\
\text { (m) }\end{array}$} \\
\hline & \multirow{2}{*}{305} & \multicolumn{5}{|c|}{ _ UVR wavelength (nm) } & \multirow{2}{*}{ PAR } & \\
\hline & & 313 & 315 & 340 & 380 & 395 & & \\
\hline 22 September 2003 & 0.228 & 0.194 & 0.168 & 0.120 & 0.071 & 0.062 & 0.069 & 21.8 \\
\hline 23 September 2003 & 0.222 & 0.173 & 0.160 & 0.120 & 0.071 & 0.062 & 0.069 & 22.8 \\
\hline 26 September 2003 & 0.223 & 0.194 & 0.190 & 0.186 & 0.106 & 0.089 & 0.072 & 25.7 \\
\hline 30 September 2003 & 0.227 & 0.165 & 0.153 & 0.120 & 0.091 & 0.076 & 0.067 & 22.7 \\
\hline 2 October 2003 & 0.239 & 0.176 & 0.162 & 0.107 & 0.098 & 0.082 & 0.073 & 22.7 \\
\hline 7 October 2003 & 0.242 & 0.221 & 0.234 & 0.163 & 0.091 & 0.076 & 0.066 & 27.7 \\
\hline
\end{tabular}


Table 3. Environmental parameters obtained near the surface $(5 \mathrm{~m})$ and at the depth of the chlorophyll maximum (DCM) in the area of study on different dates. Bold data represent the days of Expts 1 (25 September 2003) and 2 (8 October 2003). Fluorescence data presented (units $\mu \mathrm{g} \mathrm{l}^{-1}$ ) is the relative fluorescence of chl a

\begin{tabular}{|c|c|c|c|c|c|c|c|c|c|c|c|}
\hline \multirow[t]{2}{*}{ Date } & \multirow[t]{2}{*}{ Latitude } & \multirow{2}{*}{ Longitude } & \multirow{2}{*}{$\begin{array}{l}\text { Depth } \\
\text { (m) }\end{array}$} & \multirow{2}{*}{$\begin{array}{c}\text { Temperature } \\
\left({ }^{\circ} \mathrm{C}\right)\end{array}$} & \multirow{2}{*}{$\begin{array}{l}\text { Salinity } \\
\text { (PSU) }\end{array}$} & \multirow{2}{*}{$\begin{array}{l}\text { Fluorescence } \\
\qquad\left(\mu \mathrm{g} \mathrm{l}^{-1}\right)\end{array}$} & \multirow{2}{*}{$\begin{array}{c}\text { DOC } \\
\left(\mu \mathrm{mol} \mathrm{l} \mathrm{l}^{-1}\right)\end{array}$} & \multicolumn{4}{|c|}{ Nutrients $\left(\mu \mathrm{mol} \mathrm{l}^{-1}\right)$} \\
\hline & & & & & & & & $\mathrm{PO}_{4}$ & $\mathrm{NH}_{4}$ & $\mathrm{NO}_{2}$ & $\mathrm{NO}_{3}$ \\
\hline \multirow[t]{2}{*}{22 Sep 2003} & $37^{\circ} 50^{\prime} \mathrm{N}$ & $2^{\circ} 50^{\prime} \mathrm{E}$ & 5 & 25.0 & 37.3 & 0.03 & 67 & $0.017^{\mathrm{a}}$ & $0.083^{\mathrm{a}}$ & $0.003^{\mathrm{a}}$ & $0.005^{\mathrm{a}}$ \\
\hline & & & 49.5 & 14.9 & 37.3 & 0.73 & 68 & 0.025 & 0.105 & 0.150 & 0.597 \\
\hline \multirow[t]{2}{*}{23 Sep 2003} & $37^{\circ} 49^{\prime} \mathrm{N}$ & $2^{\circ} 46^{\prime} \mathrm{E}$ & 5 & 25.0 & 37.3 & 0.04 & 71 & 0.016 & 0.130 & 0.008 & 0.038 \\
\hline & & & 51.5 & 15.18 & 37.5 & 0.64 & 67 & 0.027 & 0.123 & 0.185 & 0.769 \\
\hline \multirow{2}{*}{25 Sep 2003} & $37^{\circ} 46^{\prime} \mathrm{N}$ & $2^{\circ} 32^{\prime} \mathrm{E}$ & 5 & 24.9 & 37.4 & 0.04 & - & 0.014 & 0.113 & 0.001 & 0.000 \\
\hline & & & 55.5 & 15.17 & 37.7 & 0.48 & 67 & 0.015 & 0.115 & 0.000 & 0.010 \\
\hline \multirow[t]{2}{*}{26 Sep 2003} & $37^{\circ} 43^{\prime} \mathrm{N}$ & $2^{\circ} 29^{\prime} \mathrm{E}$ & 5 & 24.8 & 37.4 & 0.04 & 75 & 0.012 & 0.129 & 0.007 & 0.037 \\
\hline & & & 54.5 & 15.07 & 37.5 & 0.61 & 68 & 0.031 & 0.118 & 0.190 & 1.027 \\
\hline \multirow[t]{2}{*}{27 Sep 2003} & $37^{\circ} 41^{\prime} \mathrm{N}$ & $2^{\circ} 15^{\prime} \mathrm{E}$ & 5 & 24.7 & 37.3 & 0.04 & 66 & 0.011 & 0.122 & 0.013 & 0.024 \\
\hline & & & 51.5 & 14.74 & 37.3 & 0.80 & 57 & 0.028 & 0.124 & 0.233 & 0.975 \\
\hline \multirow[t]{2}{*}{30 Sep 2003} & $37^{\circ} 46^{\prime} \mathrm{N}$ & $1^{\circ} 59^{\prime} \mathrm{E}$ & 5 & 24.8 & 37.3 & 0.05 & 74 & $0.007^{b}$ & $0.166^{\mathrm{b}}$ & $0.004^{\mathrm{b}}$ & $0.035^{\mathrm{b}}$ \\
\hline & & & 55 & 15.01 & 37.4 & 0.70 & 66 & 0.008 & 0.164 & 0.009 & 0.029 \\
\hline \multirow[t]{2}{*}{2 Oct 2003} & $37^{\circ} 52^{\prime} \mathrm{N}$ & $1^{\circ} 58^{\prime} \mathrm{E}$ & 5 & 24.7 & 37.3 & 0.05 & 66 & 0.014 & 0.146 & 0.007 & 0.017 \\
\hline & & & 57.5 & 14.89 & 37.4 & 0.64 & 74 & 0.025 & 0.194 & 0.132 & 0.704 \\
\hline \multirow[t]{2}{*}{8 Oct 2003} & $37^{\circ} 39^{\prime} \mathrm{N}$ & $1^{\circ} 54^{\prime} \mathrm{E}$ & 5 & 23.7 & 37.3 & 0.06 & - & - & - & - & - \\
\hline & & & 53.5 & 14.97 & 37.2 & 0.41 & - & - & - & - & - \\
\hline
\end{tabular}

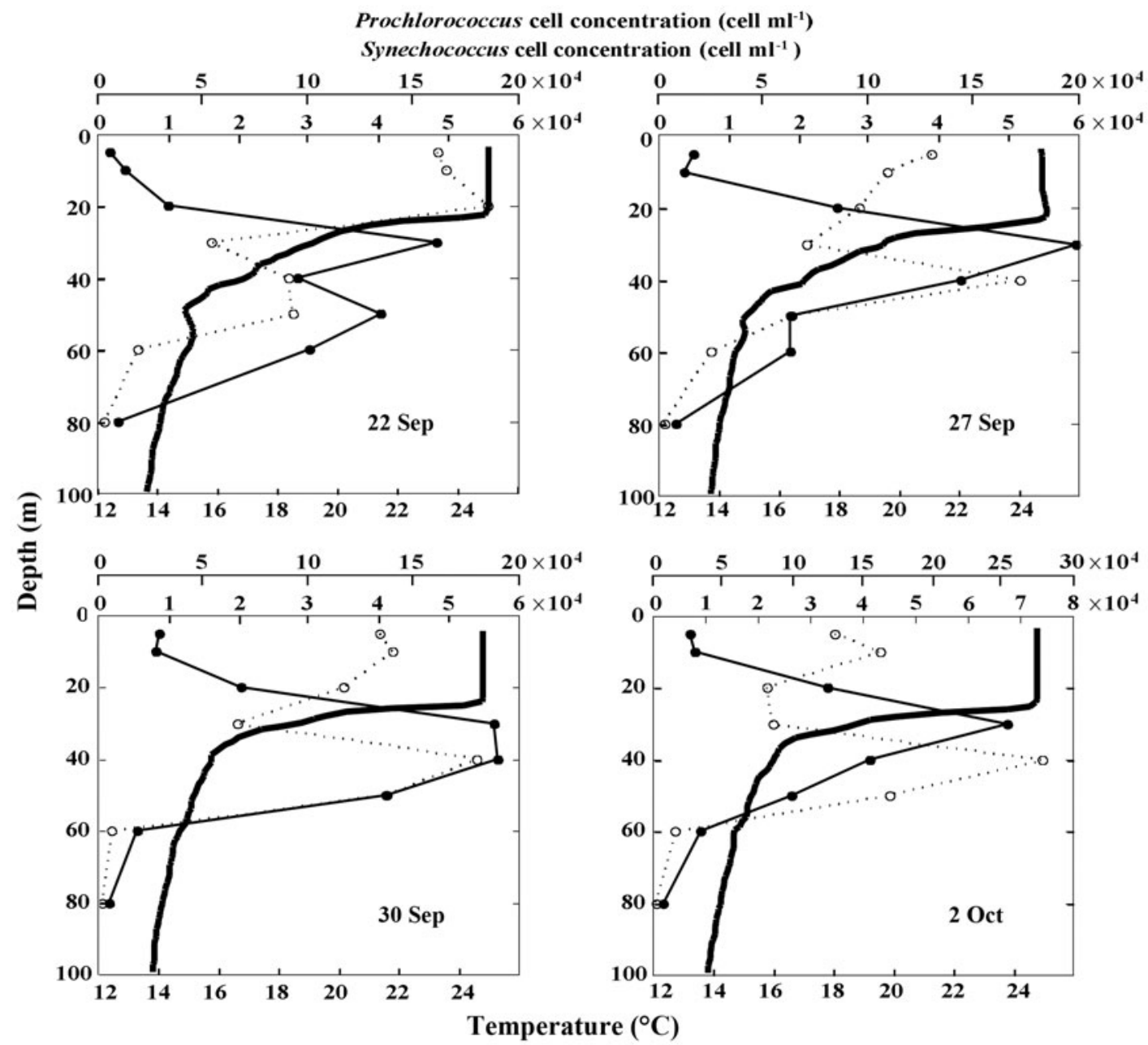

Fig. 2. Vertical distribution profiles of Prochlorococcus sp. $\left(\bullet\right.$, cell $\left.\mathrm{ml}^{-1}\right)$ and Synechococcus sp. $\left(\mathrm{O}\right.$, cell $\left.\mathrm{ml}^{-1}\right)$ and temperature (thick line, ${ }^{\circ} \mathrm{C}$ ) observed in the eddy on different dates in Mediterranean waters during September to October 2003 

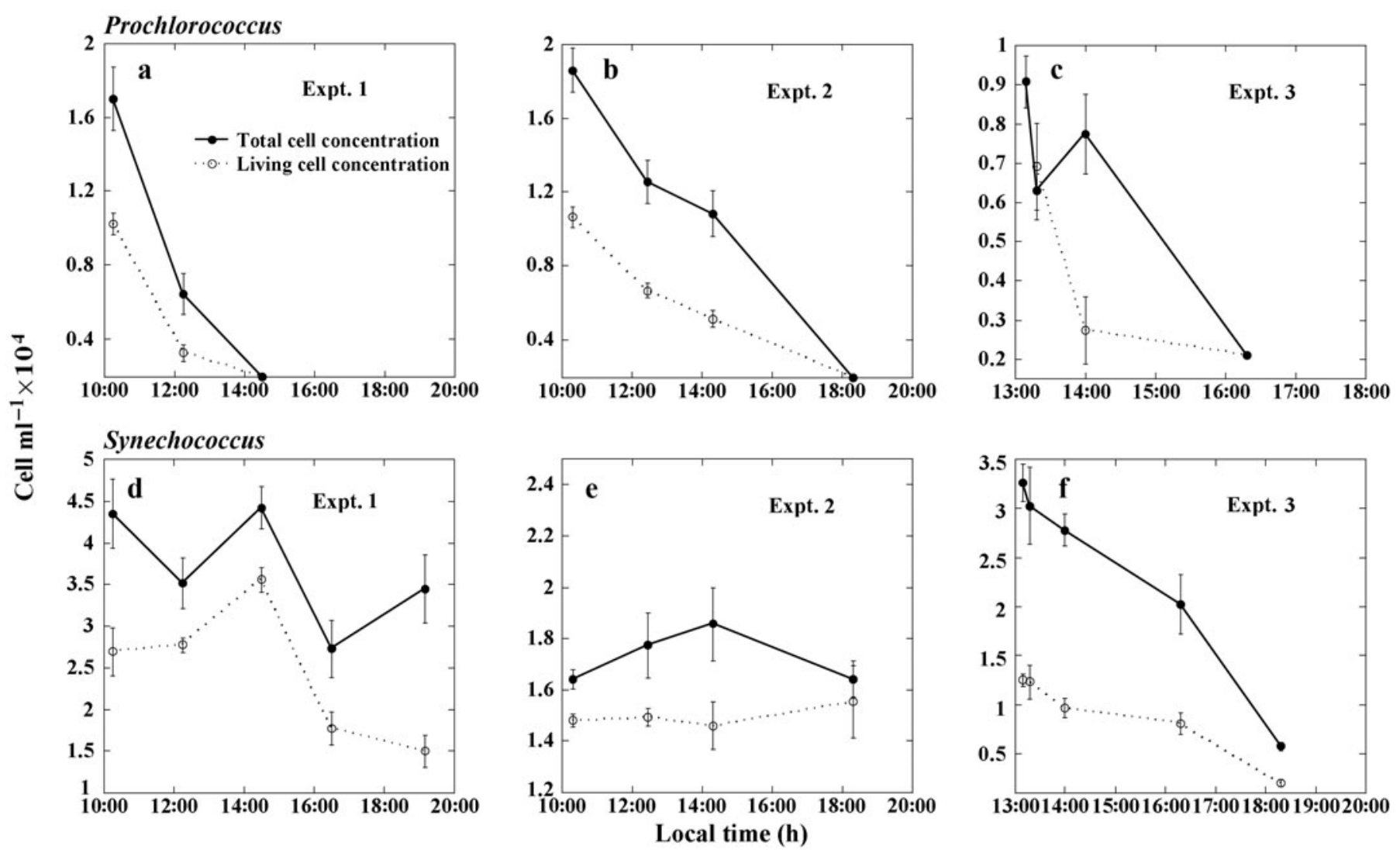

Fig. 3. Prochlorococcus and Synechococcus. Total and living cell concentrations (cell $\mathrm{ml}^{-1}$ ) of (a - c) Prochlorococcus sp. and (d - f) Synechococcus sp. obtained under full sun (FS) exposure (PAR+UVAR+UVBR) during all experiments. Error bars correspond to range of values for duplicate samples of light treatments

cus was very high, with the abundance of the total population and that of living cells decreasing below the detection limit after an exposure to solar radiation of $4 \mathrm{~h}$ (Expts 1 and 3, Fig. 3) and $8 \mathrm{~h}$ (Expt 2, Fig. 3).

In treatments without UVBR (PAR+UVAR), cell mortality was similar to that under FS (PAR+UVAR+UVBR) for Prochlorococcus sp. (Fig. 4a,b). The decrease in the abundance of living cells of Prochlorococcus in PAR+ UVAR treatments was more pronounced in Expt 1, where the abundance was below the detection limit after $6 \mathrm{~h}$ of exposure (Fig. 4a), than in Expt 2 (Fig. 4b).

Synechococcus sp. living cell abundance did not decrease under PAR+UVAR treatments in Expt 1 (Fig. 4c); however, a decrease in the abundance of living Synechococcus cells was observed at the end of Expt 2 (Fig. 4d). For both Prochlorococcus sp. and Synechococcus, no cell death was detected in the dark controls (Fig. 4). The high mortality observed for Prochlorococcus caused very short half-life times for this taxa, ranging between 1.8 and $3.3 \mathrm{~h}$ when exposed to FS (Table 4). Moreover, longer half-life times were obtained when shielding off UVBR, with an average half-life of $3 \mathrm{~h}$. The average half-life time obtained for Synechococcus for FS was 9.9 h (Table 4), much longer than that obtained for Prochlorococcus $(1.89 \mathrm{~h})$.

The variation observed in cell death and half-life values was largely dependent on the different UV doses received in the experiments. The exposure of Prochlorococcus sp. to solar UV radiation resulted in a substantial decline of its populations in all the treatments and experiments, with the abundance of living cells decreasing as the UV doses increased (Fig. 5). In contrast, Synechococcus sp. only showed a decay of its populations with increasing UVA+B doses in Expt 1 and UVA doses in Expt 2 (Fig. 5).

The lethal radiation doses needed to reduce the living fraction of the population by half, $\mathrm{LRD}_{50}$, for Prochlorococcus sp. exposed to FS varied between 140 and $279 \mathrm{~kJ}$ $\mathrm{m}^{-2}$ (Table 5). For Synechococcus sp. the $\mathrm{LRD}_{50}$ was $686 \mathrm{~kJ} \mathrm{~m}^{-2}$ for FS in Expt 1. When UVBR was shielded off, LRD ${ }_{50}$ for Prochlorococcus was $217 \pm 13 \mathrm{~kJ} \mathrm{~m}^{-2}$ $($ mean $\pm \mathrm{SE})$, much lower than that obtained for Synechococcus with $4537 \mathrm{~kJ} \mathrm{~m}^{-2}$ in Expt 2 (Table 5).

Daily underwater UV doses, determined for the period of sampling of BADE-I (September 22 to October 7, Fig. 6), indicated that UV doses equivalent to the averaged $\mathrm{LRD}_{50}$ of $187 \mathrm{~kJ} \mathrm{~m}^{-2}$ calculated for Prochloro- 


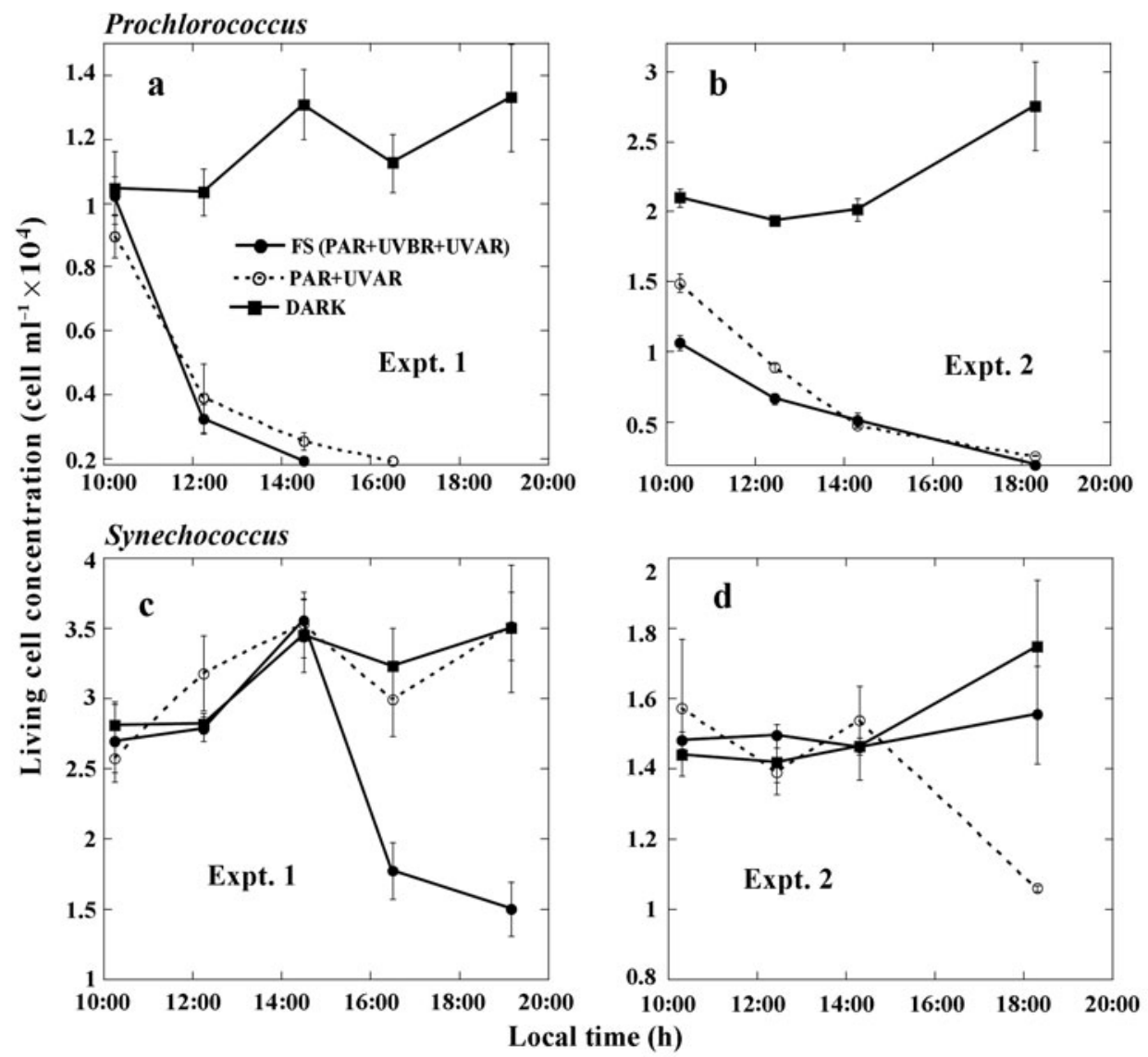

Fig. 4. Prochlorococcus and Synechococcus. Living cell concentrations of (a,b) Prochlorococcus sp. and (c,d) Synechococcus sp. obtained under full sun (FS) exposure (PAR+UVAR+UVBR), PAR+UVAR and dark treatments during Expts 1 and 2 . Error bars correspond to range of values for duplicate samples of light treatments

coccus sp. (Table 5) would penetrate to a depth varying from 10 to $26 \mathrm{~m}$ in the water column. Moreover, for Synechococcus sp. the depth receiving daily UV doses equivalent to the $\mathrm{LRD}_{50}$ of $1375 \mathrm{~kJ} \mathrm{~m}^{-2}$, resulting from the slope averages between experiments and assuming 0 when cell mortality was not detected (Table 5), was shallower, being above $5 \mathrm{~m}$ depth (Fig. 6) during the same period of sampling.

Table 4. Synechococcus and Prochlorococcus. Half-life time values, $\mathrm{t}_{1 / 2}(\mathrm{~h})$, obtained for the 3 experiments under full sun (FS) exposure (PAR+UVAR+UVBR) and PAR+UVAR treatments. Ndect: no detected mortality; -: not determined. Mean $\pm \mathrm{SE}$ values represent the lethal dose values obtained from the slope averages between experiments and assuming 0 when cell mortality was not detected. See Table 1 for abbreviations

\begin{tabular}{|lcccc|}
\hline \multirow{2}{*}{ Expt } & \multicolumn{2}{c}{ Synechococcus sp. } & \multicolumn{2}{c|}{ Prochlorococcus sp. } \\
& FS & PAR+UVAR & FS & PAR+UVAR \\
\hline 1 & 9.38 & Ndect & 1.77 & 2.90 \\
2 & Ndect & 14.91 & 3.27 & 3.13 \\
3 & 5.1 & - & 1.40 & - \\
Mean & $9.9 \pm 5.5$ & 29.82 & $1.89 \pm 0.42$ & $3.01 \pm 0.1$ \\
\pm SE & & & & \\
\hline
\end{tabular}

\section{DISCUSSION}

Our results demonstrate that picocyanobacteria in the near-surface layers of the Mediterranean Sea may be severely affected by exposure to ambient levels of ultraviolet radiation causing cell mortality. The Prochlorococcus populations analysed here, as well as those from the Atlantic Ocean examined by Llabrés \& Agustí (2006), experienced high cell death in all the experiments, indicating that the levels of photoprotection and repair systems were insufficient to repair the cell damage induced by solar radiation. Since no changes were observed in the living cell abundance of picocyanobacteria incubated in the dark (dark treatment), the cell losses observed under the light treatments can only be explained by solar radiation and not by other losses such as grazing.

Prochlorococcus sp. exhibited higher cell mortality when exposed to the FS treatment (UVBR+UVAR+ PAR); however, our results indicated that PAR+UVAR might also induce considerable cell death. Although UVBR is considered to cause the most harm in organisms, including phytoplankton (Rijstenbil 2001, Buma 

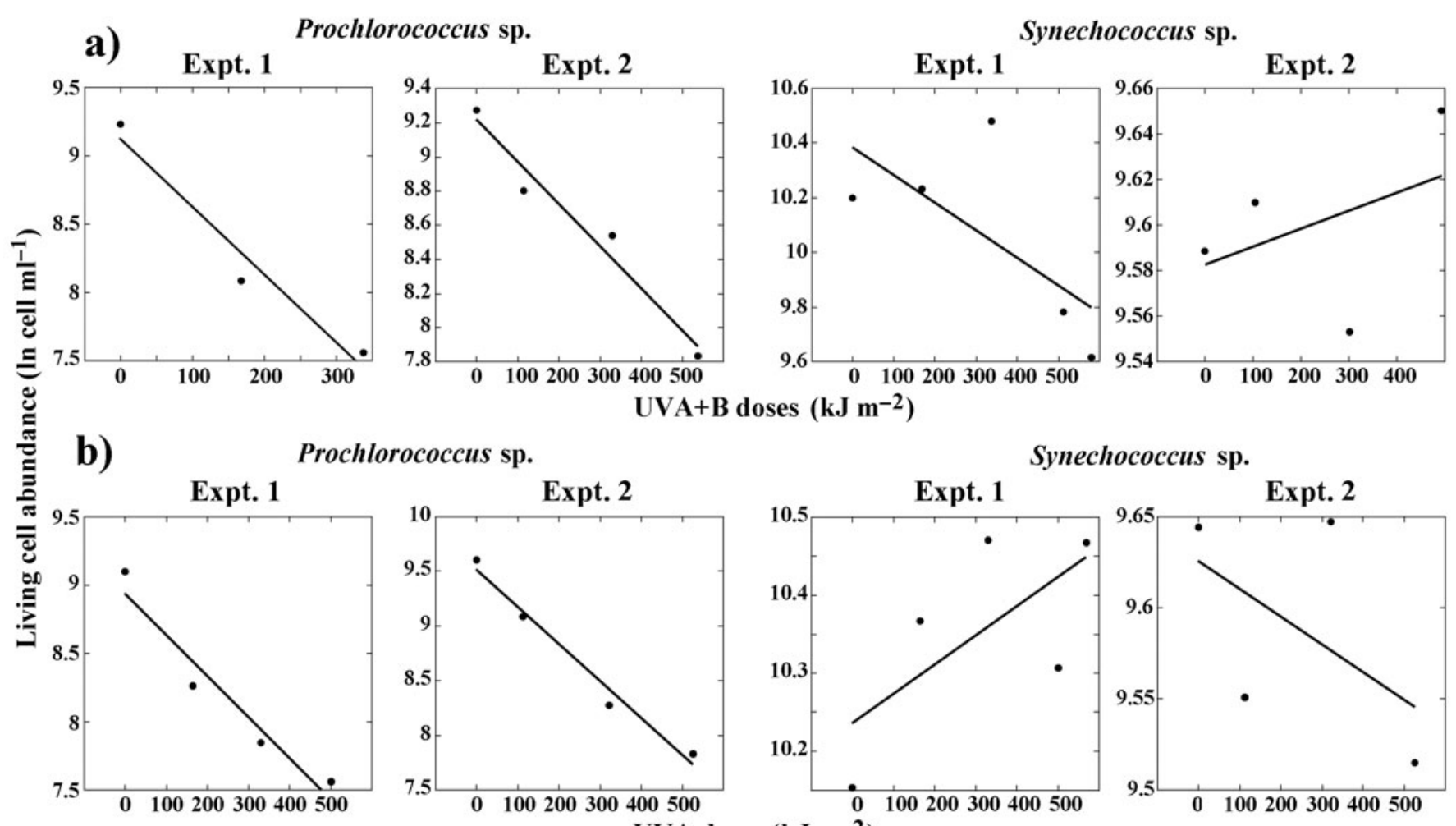

UVA+B doses $\left(\mathrm{kJ} \mathrm{m}^{-2}\right)$

Synechococcus sp.
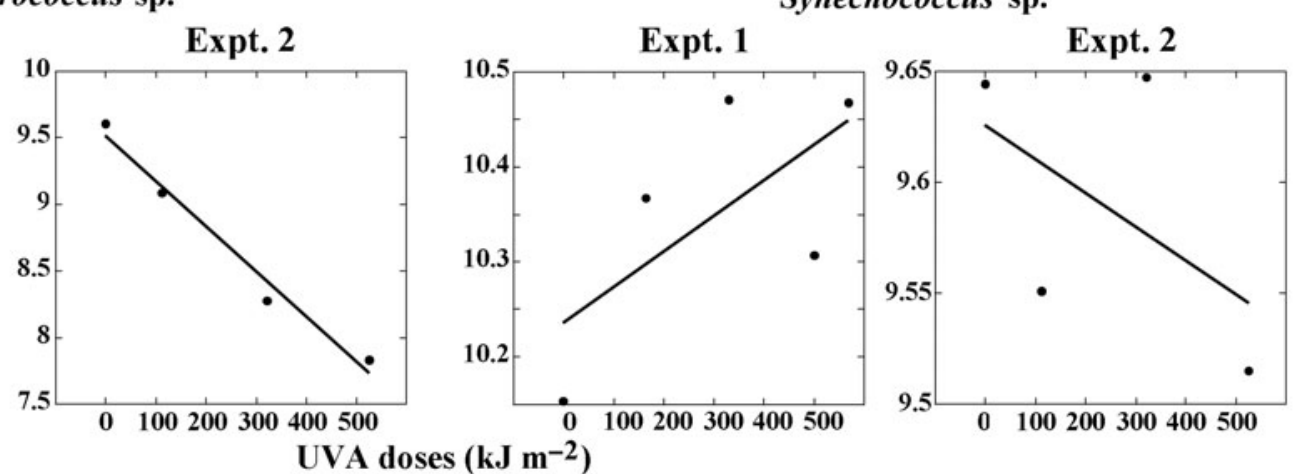

Fig. 5. Prochlorococcus and Synechococcus. Relationship between living cell abundance of Prochlorococcus sp. and Synechococcus sp. (ln cell ml $\mathrm{m}^{-1}$ ) and UV doses $\left(\mathrm{kJ} \mathrm{m}^{-2}\right.$ ) received at the different sampling events during Expts 1 and 2 . Fitted linear regressions are shown. Treatments are (a) full sun (FS: PAR+UVBR+UVAR) and (b) PAR+UVAR

et al. 2001), adverse effects of UVAR exposure are also well documented. Photosynthesis inhibition by UVAR exposure is reported for both marine and freshwater phytoplankton (Kim \& Watanabe 1994, Helbling et al. 2001), as well as inhibition of nitrogen metabolism, altering protein structure and functions (Döhler \& Buchmann 1995), and other harmful effects, such as enhancement of lipid peroxidation (MDA production, Rijstenbil 2001). On the other hand, UVAR can counteract the adverse effects of UVBR by activating repair processes (Quesada et al. 1995). Nevertheless, the present results indicate that exposure to high PAR+UVAR resulted in significant damage to Prochlorococcus, demonstrating the adverse effects of UVAR on these organisms. Recent work by Sommaruga et al. (2005), in which UVAR was shielded off, supports our conclusion. They found that Prochlorococcus exposed only to PAR experienced fewer cell losses than under UVAR exposure. In addition, in other recent studies, Prochlorococcus and Synechococcus sp. exposed only to PAR showed fewer cell losses than under FS (Llabrés \& Agustí 2006, Agustí \& Llabrés 2007).

Similar to recent results from Atlantic communities (Llabrés \& Agustí 2006), Mediterranean Synechococcus sp. showed higher resistance to UVBR, indicating that the populations examined from this genus should have better photo-protection or repair systems than Prochlorococcus sp. The high sensitivity of picophytoplankton to solar radiation has been attributed to the small size of these cells (Llabrés \& Agustí 2006), i.e. below the threshold size needed to accommodate sunscreen substances for effective cell protection (GarciaPichel 1994). Differences observed in the sensitivity to UV radiation between Synechococcus and Prochlorococcus could be better attributed to different cellular properties, such as morphology, pigment composition and DNA base content and sequence, as recent genomic studies describe some Prochlorococcus strains as lacking important genes for DNA repair (Hess et al. 2001, Dufresne et al. 2005). In contrast, Synechococcus has specific mechanisms of protection described for other cyanobacteria, as for example it can rapidly change the expression of genes encoding photosystem II D1 proteins, avoiding photosynthetic inhibition under moderate UVB exposure (Campbell et al. 1998).

The high rates of cell death in Prochlorococcus sp. reported here were induced by the exposure to high natural levels of solar radiation allowed by the experimental set-up (equivalent to that able to reach shallow depths around 0.3 to $0.5 \mathrm{~m}$ underwater), indicating that only in situ Prochlorococcus populations within the upper sub-surface layer would experience high death 
Table 5. Synechococcus and Prochlorococcus. Lethal UVA+B, UVB and UVA doses $\left(\mathrm{LRD}_{50}, \mathrm{~kJ} \mathrm{~m}^{-2}\right)$ required to reduce the populations of Synechococcus sp. and Prochlorococcus sp. to $50 \%$ in Expts 1 and 2 under full sun (FS: PAR+UVAR+UVBR) and PAR+UVAR treatments. Ndect: no detected mortality. Mean $\pm \mathrm{SE}$ values represent the lethal doses values obtained from the slope averages between experiments and assuming 0 when cell mortality was not detected. See Table 1 for abbreviations

\begin{tabular}{|c|c|c|c|c|c|c|}
\hline \multirow{3}{*}{$\begin{array}{l}\text { Expt } \\
\text { Treatment: } \\
\text { Doses: }\end{array}$} & \multicolumn{3}{|c|}{ Synechococcus sp. } & \multicolumn{3}{|c|}{ Prochlorococcus sp. } \\
\hline & 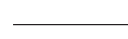 & 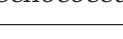 & PAR+UVAR & & & PAR+UVAR \\
\hline & $\mathrm{UVA}+\mathrm{B}$ & $(\mathrm{UVB})^{\mathrm{a}}$ & UVA & UVA+B & $(U V B)^{a}$ & UVA \\
\hline 1 & 686 & $(15.2)$ & Ndect & 140 & $(3.2)$ & 230 \\
\hline 2 & Ndect & (Ndect) & 4537 & 279 & $(5.8)$ & 205 \\
\hline Mean \pm SE & 1375 & $(30.4)$ & 9075 & $187 \pm 62$ & $(4.13 \pm 1.2)$ & $217 \pm 13$ \\
\hline
\end{tabular}

rates equivalent to those measured in the experiments. The decay rates of Prochlorococcus induced by solar radiation in situ should, however, decrease as depth increases and levels of underwater UV radiation decrease. Moreover, a longer time of Prochlorococcus exposure to reduced levels of irradiance could lead to a similar loss of cells, although occurring at a lower rate (Llabrés \& Agustí 2006), which implies that UV doses received are also important for the resulting cell death losses of the population (Llabrés \& Agustí 2006).

The Mediterranean waters studied here were transparent, showing photic depths larger than $65 \mathrm{~m}$, where UVR penetrated to a large extent in relation to PAR. UVR penetration is often calculated as the depth of the layer receiving $10 \%$ of the light at the surface (Tedetti \& Sempéré 2006); this varied from $10 \mathrm{~m}$ for UVB (at $305 \mathrm{~nm}$ ) to $27 \mathrm{~m}$ for UVA (at $380 \mathrm{~nm}$ ), which are important measures when considering that the equivalent $10 \%$ layer for PAR corresponded to $34 \mathrm{~m}$. In fact, Tedetti \& Sempéré (2006) provided depths of 9 and $16 \mathrm{~m}$ receiving the $10 \%$ UVBR in the Mediterranean Sea. The transparency in the UVB and UVA bands

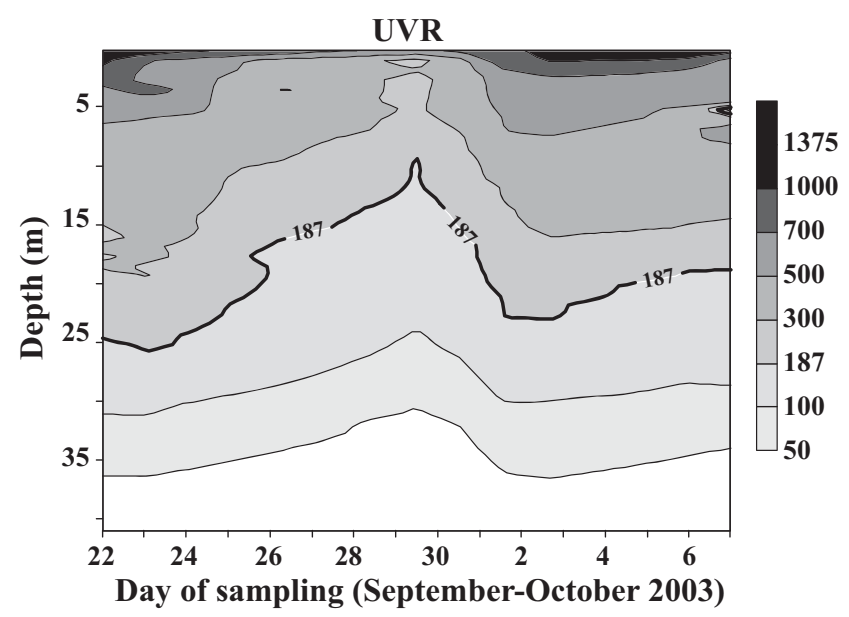

Fig. 6. Daily UV doses $\left(\mathrm{kJ} \mathrm{m}^{-2}\right)$ calculated at different depths in the water column of the Mediterranean Sea during BADE-I cruise. Thick line represents the experimental UVLRD 50 calculated for Prochlorococcus sp. obtained here for the Mediterranean Sea was equivalent to that reported for other oligotrophic areas, such as the waters around the Marquesas Islands, in the South Pacific (Morel et al. 2007, Tedetti et al. 2007), but less than that for the clearest oceanic waters, where $K_{d}$ coefficients are half the values reported here (Morel et al. 2007, Tedetti et al. 2007). Underwater penetration of UVR was transformed in this study to doses received per day, helping to relate the penetration of UV radiation with its potential damage to cyanobacterial populations. The UVR layer presenting considerable lethal effects for Synechococcus sp. populations was restricted to the upper surface, as indicated by the less than $5 \mathrm{~m}$ depth receiving the equivalent UV $\mathrm{LRD}_{50}$ calculated from the experiments. A different scenario was found for Prochlorococcus sp., for which the underwater doses able to reduce the populations by half penetrated down to $10 \mathrm{~m}$ depth on moderately cloudy days, and to $26 \mathrm{~m}$ depth on sunny days. Tedetti \& Sempéré (2006) calculated that the depth receiving the $10 \%$ of the light at the surface for DNA damage (DNA dosimeter) reaches more than $12 \mathrm{~m}$ in the Atlantic Ocean, which is consistent with our results, especially when considering that Prochlorococcus sp. is probably the most UVR-sensitive phytoplankton species (Llabrés \& Agustí 2006, Agustí \& Llabrés 2007). The deep penetration of lethal UV doses indicates that UV and solar radiation could exert a tight control over the populations of Prochlorococcus in the water column of the Mediterranean Sea. In fact, Prochlorococcus populations have been described as low in abundance during the summer time, and tend to be less abundant at the surface than Synechococcus (e.g. Vaulot et al. 1990, Alonso-Laita et al. 2005).

Total UVR doses received by phytoplankton cells would also depend on the mixing regime of the water column, since mixing could transport cells to deep layers with lower levels of UV radiation for a certain fraction of the day. However, the estimated depth for the Prochlorococcus LRD $_{50}$ covers most of the UML, leaving little shelter for Prochlorococcus cells. 
Our calculated lethal UV doses did, however, include the lethal effect induced by PAR. In order to learn about the wavelength-dependency of the effect of UV radiation on phytoplankton cell death, laboratory experiments with simulated solar radiation and specific filters should be performed to determine the biological weighting function, or UVR action spectrum, for cell death.

\section{CONCLUSIONS}

Picocyanobacterial populations from oligotrophic Mediterranean waters could be severely affected by UVR-induced cell mortality. Although UVBR was an important lethal factor, most cell death was attributed to PAR+UVAR in Prochlorococcus sp., which appears to be more sensitive to UVR than Synechococcus sp. The transparency of the water column in the Mediterranean Sea allowed a considerable penetration of UV radiation. The underwater UVR layer presenting considerable lethal effects for Synechococcus populations was limited to the upper surface, but this extended down to $26 \mathrm{~m}$ on sunny days for Prochlorococcus. Our results point to the importance of UV and solar radiation as a cell loss factor of Prochlorococcus in the Mediterranean Sea that could control the dynamics and distribution of its populations.

Acknowledgements. This study was supported by grant REN2002-10606E/MAR to S.A., funded by the Spanish Ministry of Education and Science, by the Netherlands Science Foundation, Earth and Life Sciences (NWO-ALW, project Nr. \#812.03.001 to G.J.H.), by the project EUROTROPH (Nutrients Cycling and the Trophic Status of Coastal Ecosystems) funded by FP5 of the European Union and by the Project SESAME funded also by the European Union. M.L. was supported by the project REN2001-5060E/MAR. We thank the technical personnel and crew of the RVs 'Pelagia' and 'Mytilus' for their professional assistance. We are grateful to E. Alou for sampling assistance and to C. M. Duarte for valuable comments on the manuscript.

\section{LITERATURE CITED}

Agustí S, Llabrés M (2007) Solar-radiation induced mortality of marine pico-phytoplankton in the oligotrophic ocean. Photochem Photobiol 83:739-801

Agustí S, Sánchez MC (2002) Cell viability in natural phytoplankton communities quantified by a membrane permeability probe. Limnol Oceanogr 47:818-828

Alonso-Laita P, Navarro N, Duarte CM, Agustí S (2005) Seasonality of pico-phytoplankton abundance and cell death in a Mediterranean Bay (Bay of Palma, Majorca Island). Vie Milieu 55:177-184

Blumthaler M, Ambach W (1990) Indication of increasing solar ultraviolet-B radiation flux in alpine regions. Science 248:206-208
Buma AGJ, Helbling EW, de Boer MK, Villafañe VE (2001) Patterns of DNA damage and photoinhibition in temperate South-Atlantic picophytoplankton exposed to solar ultraviolet radiation. J Photochem Photobiol B Biol 62: 9-18

Campbell D, Eriksson MJ, Öquist G, Gustafsson P, Clarke AK (1998) The cyanobacterium Synechococcus resists UVBby exchanging photosystem II reaction-center D1 proteins. Proc Natl Acad Sci USA 95:364-369

Conan P, Joux F, Torréton JP, Pujo-Pay M, Douki T, RochelleNewall E, Mari X (2008) Effect of solar ultraviolet radiation on bacterio- and phytoplankton activity in a large coral reef lagoon (southwest New Caledonia). Aquat Microb Ecol 52:83-98

Cullen JJ, Neale PJ, Lesser MP (1992) Biological weighting function for the inhibition of phytoplankton photosynthesis by ultraviolet radiation. Science 258:646-650

Döhler G, Buchmann T (1995) Effects of UV-A and UV-B irradiance on pigments and ${ }^{15} \mathrm{~N}$-ammonium assimilation of the haptophycean Pavlova. J Plant Physiol 146:29-34

- Dufresne A, Garczarek L, Partensky F (2005) Accelerated evolution associated with genome reduction in a freeliving prokaryote. Genome Biol 6:R14

Forster RM, Haxer A, Schubert H (1997) Wavelength dependence of photoinhibition in the green alga Chlorella vulgaris. Photosynthetica 33:541-552

Garcia-Pichel F (1994) A model for internal self-shading in planktonic organisms and its implications for the usefulness of ultraviolet sunscreen. Limnol Oceanogr 39:1704-1717

Gordon LI, Jennings JCJ, Ross AA, Krest JM (1993) A suggested protocol for continuous flow automated analysis of seawater nutrients (phosphate, nitrate, nitrite and silic acid) in the WOCE hydrographic program and the Joint Global Ocean Fluxes Study. In: WOCE operations manual. WOCE report no. 68/91, revision 1. WHP Office Report WHPO91-1. Woods Hole Oceanographic Institution, Woods Hole, MA

Helbling EW, Buma AGJ, Karin De Boer M, Villafañe VE (2001) In situ impact of solar ultraviolet radiation on photosynthesis and DNA in temperate marine phytoplankton. Mar Ecol Prog Ser 211:43-49

Hess WR, Rocap G, Ting CS, Larimer F, Stilwagen S, Lamerdin J, Chisholm SW (2001) The photosynthetic apparatus of Prochlorococcus: insights through comparative genomics. Photosynth Res 70:53-71

Keisler HJ (1986) Elementary calculus: an approach using infinitesimals. Prindle, Weber \& Schmidt, Boston, MA

$>$ Kim D, Watanabe Y (1994) Inhibition of growth and photosynthesis of freshwater phytoplankton by ultraviolet A (UVA) radiation and subsequent recovery from stress. J Plankton Res 16:1645-1654

Llabrés M, Agustí S (2006) Picophytoplankton cell death induced by UV radiation: evidence for oceanic Atlantic communities. Limnol Oceanogr 51:21-29

> Madronich RL, Mackenzie RL, Björn LO, Caldwell MM (1998) Changes in biologically active ultraviolet radiation reaching the Earth's surface. J Photochem Photobiol B Biol 46:5-19

Morel A, Gentili B, Claustre H, Babin M, Bricaud A, Ras J, Tièche F (2007) Optical properties of the 'clearest' natural waters. Limnol Oceanogr 52:217-229

Pascual A, Emelianov M, Larnicol G, Gomis D, Salat J, Buongiorno-Nardelli B, D'Acunzo E (2000) Detection by altimetry and AVHRR images of an intense anticyclonic eddy in the Balearic Sea (Western Mediterranean). Proc SPIE 4172:31-36

Quesada A, Mouget J, Vincent WF (1995) Growth of Antartic 
cyanobacteria under ultraviolet radiation: UVA counteracts UVB inhibition. J Phycol 31:242-248

Rijstenbil JW (2001) Effects of periodic, low UVA radiation on cell characteristics and oxidative stress in the marine planktonic diatom Ditylum brightwellii. Eur J Phycol 36: $1-8$

Roy S (1999) Strategies for the minimisation of UV-induced damage. In: de Mora S, Demers S, Vernet M (eds) The effects of UV radiation in the marine environment. Cambridge University Press, New York, p 177-205

Sommaruga R, Hofer JS, Alonso-Sáez L, Gasol JM (2005) Differential sunlight sensitivity of picophytoplankton from surface Mediterranean coastal waters. Appl Environ Microbiol 71:2154-2157

Tedetti M, Sempéré R (2006) Penetration of ultraviolet radia-

Editorial responsibility: Alain Vézina,

Dartmouth, Nova Scotia, Canada tion in the marine environment. a review. Photochem Photobiol 82:389-397

Tedetti M, Sempéré R, Vasilkov A, Charrière B and others (2007) High penetration of ultraviolet radiation in the south east Pacific waters. Geophys Res Lett 34, L12610

Vaulot D, Partensky F, Neveux J, Mantoura RFC, Lewellyn C (1990) Winter presence of prochlorophytes in surface waters of the northwestern Mediterranean Sea. Limnol Oceanogr 35:1156-1164

Vincent WF, Neale PJ (2000) Mechanisms of UV damage to aquatic organisms. In: de Mora S, Demers S, Vernet M (eds) The effects of UV radiation in the marine environment. Cambridge University Press, New York, p 149-176

Weatherhead EC, Andersen SB (2006) The search for signs of recovery of the ozone layer. Nature 441:39-45

Submitted: July 25, 2008; Accepted: September 21, 2009 Proofs received from author(s): January 21, 2010 